\title{
ESTIMATION OF SHALLOW GROUNDWATER RECHARGE USING A GIS-BASED DISTRIBUTED WATER BALANCE MODEL
}

\author{
Renata GraF ${ }^{1}$, Jan PrzybyeeK ${ }^{2}$ \\ ${ }^{1}$ Department of Hydrology and Water Management, Institute of Physical Geography and Environmental \\ Planning, Adam Mickiewicz University in Poznań, Poland \\ ${ }^{2}$ Department of Hydrogeology and Water Protection, Institute of Geology, Adam Mickiewicz University \\ in Poznań, Poland
}

Manuscript received: May 30, 2014

Revised version: August 5, 2014

\begin{abstract}
Graf R., PrZYBYŁeK J., 2014. Estimation of shallow groundwater recharge using a GIS-based distributed water balance model. Quaestiones Geographicae 33(3), Bogucki Wydawnictwo Naukowe, Poznań, pp. 27-37, 3 tables, 4 figs. DOI 10.2478/quageo-2014-0027, ISSN 0137-477X.

АвSTRACT: In the paper we present the results of shallow groundwater recharge estimation using the WetSpass GISbased distributed water balance model. By taking into account WetSpass, which stands for Water an Energy Transfer between Soil, Plants and Atmosphere under quasi-Steady State, for average conditions during the period 1961-2000, we assessed the spatial conditions of the groundwater infiltration recharge process of shallow circulation systems in the Poznan Plateau area (the Great Poland Lowland in western Poland), which is classified as a region with observed water deficits. For three temporal variants, i.e. year, winter and summer half-years, we determined using the geological infiltration method by about $5-10 \%$ on average, marginally by $20 \%$.
\end{abstract}

KEY WORDS: groundwater, recharge, distributed water balance, WetSpass model, Poznan Plateau

Address of the corresponding author: Renata Graf, Department of Hydrology and Water Management, Institute of Physical Geography and Environmental Planning, Adam Mickiewicz University in Poznan, Dzięgielowa 27, 61-680 Poznań, Poland; e-mail: rengraf@amu.edu.pl

\section{Introduction}

Hydrological processes occurring in the catchment are highly dynamic and their continuity or discontinuity presents a significant problem in describing and visualising the spatial and temporal relations occurring between them. Estimation of water balance components, which consists in selecting the right input data and boundary conditions, assumes the creation of a model in which there can be variation of the process, with the lowest possible number of defining variables (Soczyńska 1989, Ponce, Shetty 1995, Fiedler, Ramirez 2000, Batelaan, De Smedt 2001, Dąbrowski et al. 2011). A model with spa- tially distributed parameters (i.e. a raster model) provides information on the diversity of water balance components, i.e. precipitation, effective infiltration, surface runoff and evapotranspiration, whose spatial distribution is assigned to raster cells with a homogeneous structure. These function as balance cells and the significance of the impact of climatic and environmental factors is defined by the scale of a given study (Nawalany 1999, Blöeschl 2001, Gutry-Korycka 2001, Lin, Rathbun 2003, Sivapalan 2005, Urbański 2008).

The character of the so-called active area surface, which is assigned a specific hydrological potential and activity, particularly with respect to its preconditions for the process of groundwater 
recharge in shallow aquifers, is of vital importance in spatial analysis of hydrological processes. This process is accompanied by high effective infiltration of precipitation, which is a fundamental component of the groundwater recharge vector. The recharge boundary of a groundwater circulation system is defined as a permeable boundary with a specified hydraulic head, with water flowing into the system under natural conditions or ones affected by its exploitation (Toth 2009). The active surface of a catchment is usually characterised by a diverse structure which, as a result of the activity of a set of physical characteristics, climatic factors and elements of water circulation, influences the rate, volume and spatial distribution of the infiltration recharge of shallow aquifers. The conceptual model of the groundwater recharge process accounts for identifying the scale of the hydrological process, the inlets and outlets of the water circulation system as well as its temporal and spatial limitations, such as an area's infiltration predisposition and the type or character of a hydrologically active zone (Yair, Kossovsky 2002, Dripps, Bradbury 2007, Sorooshian, Hsu 2008, Teklebirhan et al. 2012). An extensive review of the methods and techniques for groundwater recharge estimation was presented by Pleczyński (1981), Jokiel (1994), Scanlon et al. (2002) and Batelaan (2006). Studies on groundwater recharge, conducted in areas with diverse climatic and environmental conditions, have contributed to the development of estimation methods based on statistical analyses and to classification using GIS techniques (Sophocleous 2005, Batelaan, De Smedt 2001, Batelaan 2006, Hart et al. 2012). In hydrological models that apply GIS techniques, the infiltration recharge volume of groundwater simulated in a single balance (raster) cell or in HRUs (Hydrologic Response Units) is the result of aggregating the impact of the elements of both climate and water circulation as well as geology-soil-topography association, vegetation type and land use. These concepts have been used, for instance, in such models as: HE MIKE, SWAP, SWAT, SWB, WetSpa or WetSpass, which estimate the spatial distribution of water balance components under different environmental conditions (Batelaan, De Smedt 2001, Kajewski 2004, Pokojska 2004, Cherkauer, Ansari 2005, Choromański, Michałowski
2011, Piniewski, Okruszko 2011, Graf 2012, Graf, Kajewski 2013).

\section{Aim and study area}

Assessment of the areal water balance structure of a catchment requires the identification of interrelated elements of the environment by simultaneously taking into account their spatial aspect. These criteria are fulfilled on a regional and local scale by the WetSpass model (Water an Energy Transfer between Soil, Plants and Atmosphere under quasi-Steady State; Batelaan, De Smedt 2001), which was used in the assessment of spatial conditions for the groundwater infiltration recharge process of shallow aquifers in the Poznan Plateau (the Great Poland Lowland in western Poland), classified as a region with observed water deficits (Fig. 1). The WetSpass model integrated with the GIS utilises a number of empirical relations occurring between the atmosphere, soil and plant media with respect to water and energy exchange, thus simulating the spatial distribution of effective infiltration of precipitation, surface runoff and actual evapotranspiration in relation to the average hydrometeorological conditions. The areal water balance for the region was simulated at the balance cell level $\left(x y=0.0625 \mathrm{~km}^{2}\right)$ with a specified active surface type with respect to generating hydrological processes. The period 1961-2000 was covered in the model studies, and for annual and semi-annual projections input data were prepared in the form of raster maps of climatic elements, water circulation and selected physical characteristics of the catchment (Fig. 1). The analysis of the conditions and spatial distribution of the volume of effective infiltration of precipitation was conducted in stages by identifying the preferential zones in the recharge profile, analysing the relation between infiltration and climatic and environmental variables, and developing typical and dominant models of the infiltration recharge surface of shallow groundwater in the region. The purpose of applying raster analysis in the research on hydrological processes occurring in a lowland region was to indicate the reference area of shallow groundwater recharge by assessing the dominant and accessory characteristics. 


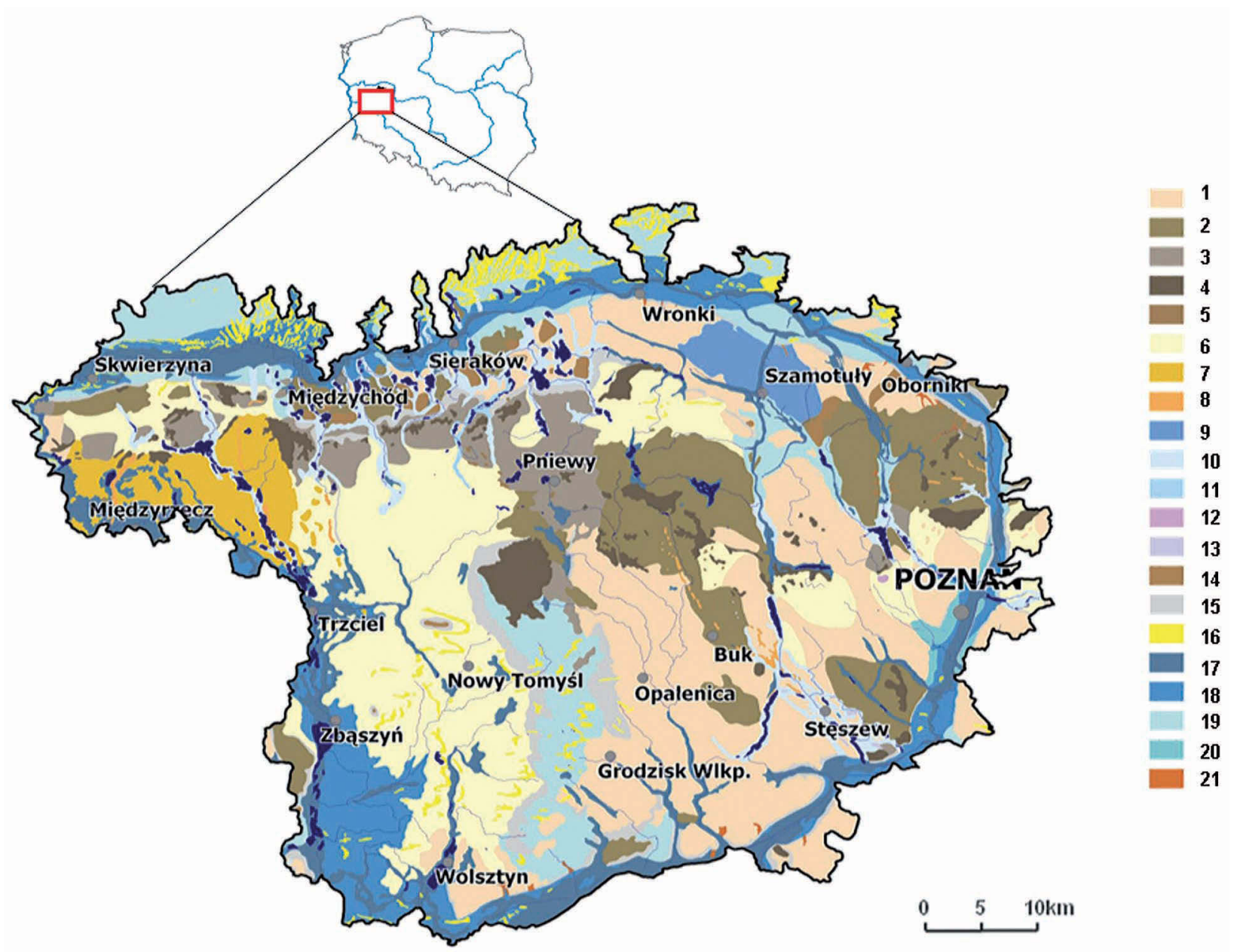

Fig. 1. Location and geomorphological conditions of the Poznan Plateau: 1- flat moraine plateau, 2 - undulating moraine plateau, 3 - hummocky moraine plateau, 4 - terminal moraine hill zone, 5 - isolated moraine hills, 6 - sandurs, 7 - kames, 8 - eskers, 9 - lacustrine plains, 10 - flat bottom troughs, 11 - rolling bottom troughs, 12 - small kettle hole clusters, 13 - single kettle holes, 14 - remnant hills, 15 - terrace treads, risers, 16 - dune hills, 17 - fluvial terrace, basin bottoms, 18 - intermediate dune terrace, 19 - high terrace - lower, 20 - high terrace - upper, 21 - small valleys and ravines (Data source: GIS database of the Geomorphological Map of the Great Poland Lowland)

The Poznan Plateau, selected as the test area $\left(5,872 \mathrm{~km}^{2}\right)$, is located in the central part of the Poznan Lowland (western Poland). In territorial structure it is delimited by the river valleys of the Warta in the north and east and by Warta's tributary, the Obra, in the south and west. The study area, examined in detail with respect to its physicogeographical conditions by Graf (2012), is characterised by a considerable diversity of morphological forms (Fig. 1), whose origin is related primarily to the processes which shaped the lay of the land during the Frankfurt and Brandenburg stages of the last glacial period. Elevated units $(62 \%)$ prevail in the region, and variation in the area's altitudes is $24.1-145.6 \mathrm{~m}$ a.s.l., with an average of $74.9 \mathrm{~m}$ a.s.l. $(\sigma=17.4)$. There is a slight share of zones with a slope above $2^{\circ}(15 \%)$, which results from the area's lowland character. The subsurface and surface zones of the Poznan Plateau are composed almost exclusively of Quaternary deposits, and deposits from earlier periods occur sparsely (the Warta valley). Low-permeability soils prevail in the central and eastern parts (loams), whereas medium permeability soils (fluvioglacial and river sands) prevail in the western and northern parts (Fig. 1). Anthropogenic soils characterised by varying permeability occur in developed and urbanised areas. The land use structure is dominated by arable land (54.8\%), whereas forest and grassland take up $32.8 \%$ and $7 \%$, respectively, which is characteristic of the Great Poland Lowland.

The Poznan Plateau is situated within the Warta basin (a tributary of the Oder). The struc- 
ture of the river network and the direction of its drainage are connected with the run of the Urstromtal sections: the Torun-Eberswalde Urstromtal in the north and the Warta-Oder Urstromtal in the south of the region as well as the valley gorge sections of the Warta and Obra (Fig. 1). A distinct connection with the land form is shown by the first aquifer groundwater drained by the hydrographic network and recharged by precipitation infiltration, which forms the soil horizon of the valley (0-2 m), sandurs (2-5 m) and the upper horizon between loam strata in the plateau (above 5-10 m).

The regional uniformity of the Poznan Plateau results from its climatic and hydrological conditions as well as by its being situated in the centre of the Warta basin, which is characterised by the lowest precipitation in Poland (below $550 \mathrm{~mm}$ ) and a low drainage ratio, on average within $\mathrm{q}=2.5-3.0 \mathrm{dm}^{3} \mathrm{~s}^{-1} \mathrm{~km}^{-2}$ (Dynowska, Pociask-Karteczka 1999, Graf 2012). The precipitation deficiency and high evaporation losses in the western Great Poland region result partly from the transformation of the inflowing masses of air and from more frequent occurrence of unfavourable pressure systems (Farat 2004, Woś 2010).

\section{Materials and methods}

The WetSpass model of the years and winter and summer half-years (1961-2000) required the creation of spatial models (raster data structure) of: the area-averaged sum of precipitation, air temperature, wind speed and potential evapotranspiration (reference evaporation) as well as the types of land cover and use, soils, slope and groundwater table level of the first aquifer (Fig. 2). Models with raster cell dimensions of $0.25 \times$ $0.25 \mathrm{~km}=0.0625 \mathrm{~km}^{2}$ were used in the estimation procedure.

The average precipitation in the catchment was selected as the precipitation recharge potential in the WetSpass model. A measurement data set collected from 18 IMGW-PIB (Institute of Meteorology and Water Management - National Research Institute) weather stations located within the Poznan Plateau region (1961-2000) was used to calculate it. A similar procedure was applied to estimate the spatial distribution of air tempera-

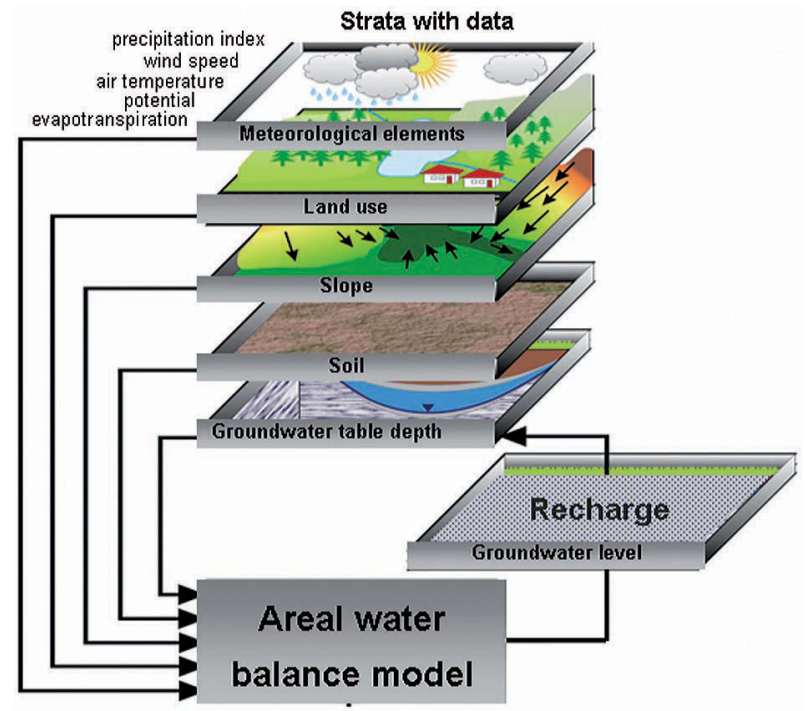

Fig. 2. Schematisation and integration of data for a hypothetical raster cell in the WetSpass water balance model, after Batelaan and De Smedt (2001)

ture and wind speed. The potential evapotranspiration was determined using the Penman-Monteith method (FAO-PM 1998), and its calculations used meteorological data for the Poznan station (1961-2000). The remaining group of input elements for the WetSpass model was prepared on the basis of digital thematic GIS databases and the land form model. Information on land cover and use were obtained from the CORINE Land Cover database (CLC 2000), identifying 15 land cover forms in the study area. A schematisation of the soil and lithological conditions, aggregation of spatial data from the Detailed Geological Map of Poland (PIG-PIB - The Polish Geological Institute - National Research Institute) as well as the GIS database of the Hydrographic Map of Poland in a scale of 1: 50,000 (GUGiK - Head Office of Geodesy and Cartography) provided an information database collated for five basic soil types with an assigned identification code as is obligatory in the WetSpass model. The slope was analysed as a derivative of the numerical land form DTED 2 in the PUWG 1992 system, in which the precision and accuracy of the data correspond to the contour interval on the maps in a scale of 1:50,000. For the analysis of spatial distribution of shallow groundwater table depths, hydroisobath maps of the GIS hydrographic database (source: Hydrographic Map 1:50,000) were used, processing the information by kriging (Surfer 9.0) into the form of regionalised data (grid). In order to 
obtain comparable data and to determine boundary values of the groundwater circulation system for average and extreme conditions for the period 1961-2000, information was supplemented with a description of the characteristics of their regime obtained from the stationary groundwater monitoring network of the IMGW-PIB.

The raster data models that were obtained are a result of modelling the spatial distribution of characteristics in a raster cell $\left(x, y=0.0625 \mathrm{~km}^{2}\right)$ with the dimensions matched to the effect of the process scale (Urbański 2008). The raster scale is characterised by a specific location in space with a quantitative or qualitative characteristic assigned to it, or a value specifying its class or intensification of occurrence. The quality of the model was verified by evaluating the modelling error $(+/-\mathrm{mm})$ in annual and seasonal simulations. Information in the form of seasonal change sequences was encoded in the waterfall model of the propagation of processes of precipitation, surface runoff, evapotranspiration and infiltration groundwater recharge. Due to the model's methodological premises regarding quantitative and descriptive information encoding, classification and reclassification procedures were used relating to the combination or separation of source data groups and to assigning them to the WetSpass database. Descriptions of source material selection and spatial data processing for the model have been presented by, e.g.: Batelaan, De Smedt (2001), Kajewski (2004), Pokojska (2004), Abu-Saleem et al. (2010), Aish et al. (2010) and Graf (2012).

\section{Results}

Simulation studies in the WetSpass model confirmed the low precipitation recharge poten- tial in the Poznan Plateau region. The mean annual precipitation (1961-2000) assigned to a balance cell $\left(x y=0.0625 \mathrm{~km}^{2}\right)$ reached values within $17-579 \mathrm{~mm}$, with an average of $541 \mathrm{~mm}(\sigma=9.9)$ - Table 1. Zones with a precipitation sum that is approximating and below the annual mean occupy $26 \%$ and $42 \%$ of the area, respectively.

A predominance of actual evapotranspiration $(79 \%)$, also characterised by the highest areal variation range $(350 \mathrm{~mm})$, is recorded in the annual water balance structure. Effective infiltration amounts to $15 \%$ and surface runoff to $6 \%$ of the precipitation (Table 1).

The mean annual effective infiltration of precipitation (IE) estimated for the Poznan Plateau region is $84 \mathrm{~mm}$, and in the spatial distribution the uniform area is represented by a range of variation of 50-100 mm (Fig. 3). An upward tendency of the variable value above $100 \mathrm{~mm}$ is visible in the north-western and north-eastern parts of the studied region. The lowest effective infiltration values of precipitation were recorded in the Poznan city area and its peripheral zone (the eastern part of the area) and in the border areas of the Lwówecko-Rakoniewicki Levee (the western part). Balance cells with a "negative IE value" which overlap with the locations of valley depressions were found in the model. These were selected as local evapotranspiration increase zones in which effective groundwater infiltration recharge is partially or completely reduced.

Effective infiltration for the winter half-year is $127 \mathrm{~mm}$, which is $59 \%$ of the precipitation sum for the half-year studied (1961-2000) - Table 1. In the studied period the areal model of effective infiltration of precipitation constitutes a strong representation of relations between its volume and the type of soils and their permeability. The uniform area is represented by a zone of infiltration

Table 1. Water balance structure [mm] for the Poznan Plateau area - WetSpass model results (1961-2000)

\begin{tabular}{|l|c|c|c|c|c|c|c|c|c|}
\hline \multirow{2}{*}{\begin{tabular}{c} 
Water balance \\
\multicolumn{1}{c|}{ components }
\end{tabular}} & \multicolumn{3}{c|}{ Year } & \multicolumn{3}{c|}{ Winter half-year } & \multicolumn{3}{c|}{ Sommer half-year } \\
\cline { 2 - 10 } & Range* $^{*}$ & $\bar{X}$ & {$[\sigma]$} & Range* $^{*}$ & $\bar{X}$ & {$[\sigma]$} & Range* $^{*}$ & $\bar{X}$ & {$[\sigma]$} \\
\hline Precipitation (P) & $517-579$ & 541 & 9.9 & $190-237$ & 215 & 8.6 & $315-351$ & 326 & 4.5 \\
\hline Effective infiltration (IE) & $(-251)-207$ & 84 & 35 & $(-33)-168$ & 127 & 24 & $(-287)-75$ & $(-43)$ & 25 \\
\hline Surface runoff (Hp) & $0.93-271$ & 31 & 39 & $0.14-179$ & 10 & 22 & $0-151$ & 20 & 23 \\
\hline Actual evapotranspiration (ET=E+T+Ic) & $274-625$ & 429 & 42 & $60-95$ & 76 & 7 & $199-550$ & 352 & 39 \\
\hline Soil evaporation (E) & $0-379$ & 77 & 58 & $0-75$ & 46 & 32 & $0-304$ & 31 & 27 \\
\hline Transpiration (T) & $0-482$ & 247 & 49 & $0-54$ & 7 & 14 & $0-429$ & 239 & 44 \\
\hline Intercepion (Ic) & $0-224$ & 89 & 75 & $0-67$ & 20 & 28 & $0-157$ & 68 & 48 \\
\hline
\end{tabular}

* Data refer to single raster cells $x y=0.0625 \mathrm{~km}^{2}$. Water balance downward bias: $\pm 1-5 \mathrm{~mm}(\delta=0.24-2 \%)$. $\bar{X}-$ mean value, $\sigma-$ standard deviation 


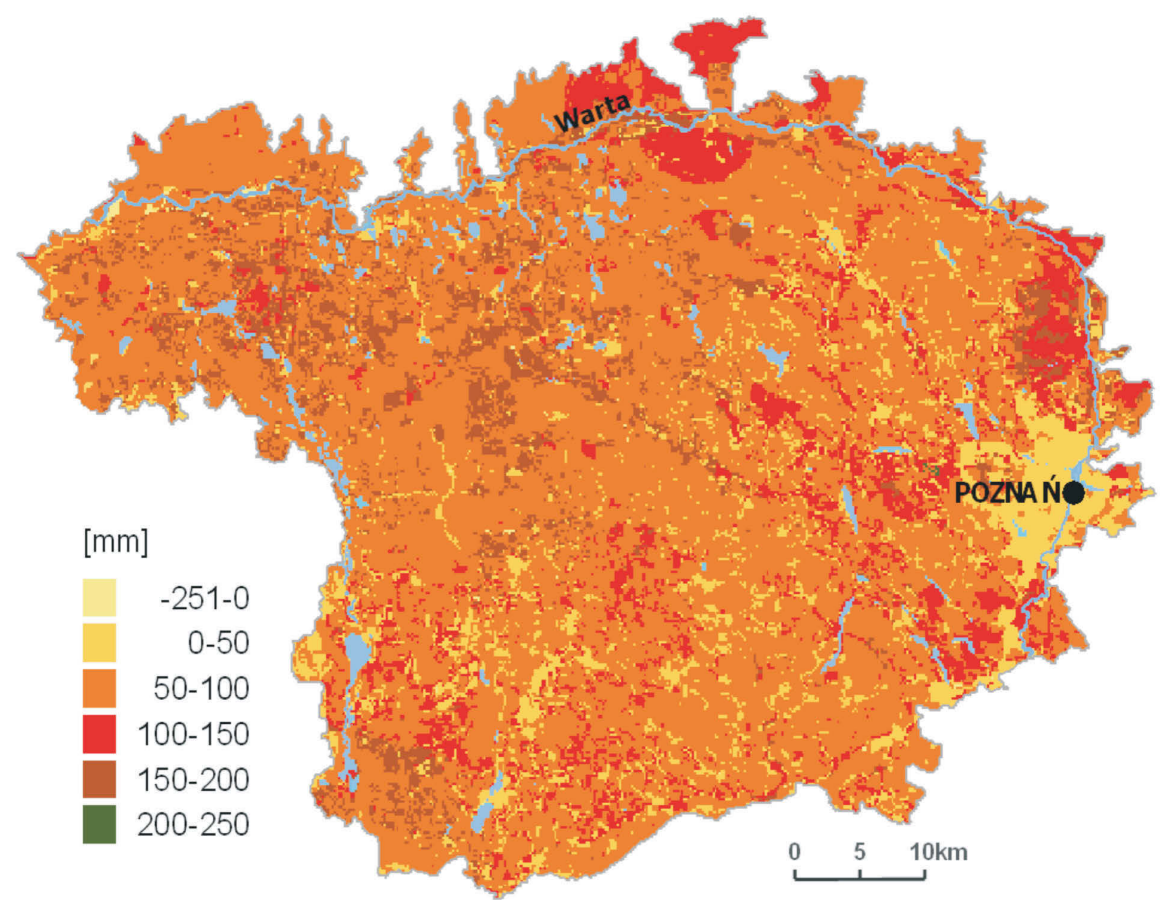

Fig. 3. Areal distribution of mean annual effective infiltration (1961-2000) in the Poznan Plateau region - WetSpass model result (1961-2000). The information values are matched with raster (balance) cells with the area of $x y=0.0625 \mathrm{~km}^{2}$

recharge in excess of $100 \mathrm{~mm}$ whose area overlaps with the coverage of formations with good and medium permeability (sands and gravels), whereas values below this boundary show high spatial distribution. The spatial model prepared for the summer half-year showed a uniform zone of negative effective infiltration values in the Poznan Plateau ( $84 \%$ of the surface), which indicates an absence of this process being manifested and activation of evapotranspiration $(E P=353$ $\mathrm{mm})$, which in the season in question exceeds the amount of precipitation $(\mathrm{P}=326 \mathrm{~mm})$.

An analysis of the raster cell frequency conducted in the WetSpass model showed that $67 \%$ of their numbers $\left(62,707\right.$ rasters $\left.=3919 \mathrm{~km}^{2}\right)$ are characterised by a mean annual effective infiltration value in the range of $50-100 \mathrm{~mm}$ (Fig. $3)$, whereas in the winter half-year balance cells become dominant $(86 \%)$, where effective infiltration varies in the range of $100-150 \mathrm{~mm}$.

\section{Discussion of the results}

The areal water balance of the Poznan Plateau, as calculated in the WetSpass model, is typical of the central part of the Great Poland Lowland, which is characterised by high water deficits. Under average annual conditions (19612000) the balance structure becomes dominated by evapotranspiration $(80 \%)$, and the relation between effective infiltration and surface runoff is approximately $3: 1$. (Table 1). Intensifying the process of infiltration recharge of groundwater in the winter season (a 50-60\% share), mostly at the expense of reduced evapotranspiration, results in an increase in its levels and soil retention, which is characteristic of an oceanic groundwater regime (Chełmicki 1991). This is confirmed by the results of analyses of fluctuations and the rise of the groundwater table in the Poznan Plateau area, based on the measurement series (19612000) of groundwater levels by IMGW-PIB (Graf 2012; Fig. 4).

Effective infiltration in the summer season is either reduced or the process ceases altogether (negative values in the model), with an estimated evapotranspiration volume of ET $=350 \mathrm{~mm}$, i.e. one which exceeds the half-year precipitation sum by about $10 \%$ (Table 1 ). Such a situation occurs chiefly in the valley portions of groundwater drainage zones, which is connected with high plant transpiration in areas with low groundwater levels (Batelaan 2006, Dripps, Bradbury 2007). In the Great Poland Lowland, in the summer half-year and under normal conditions, about 


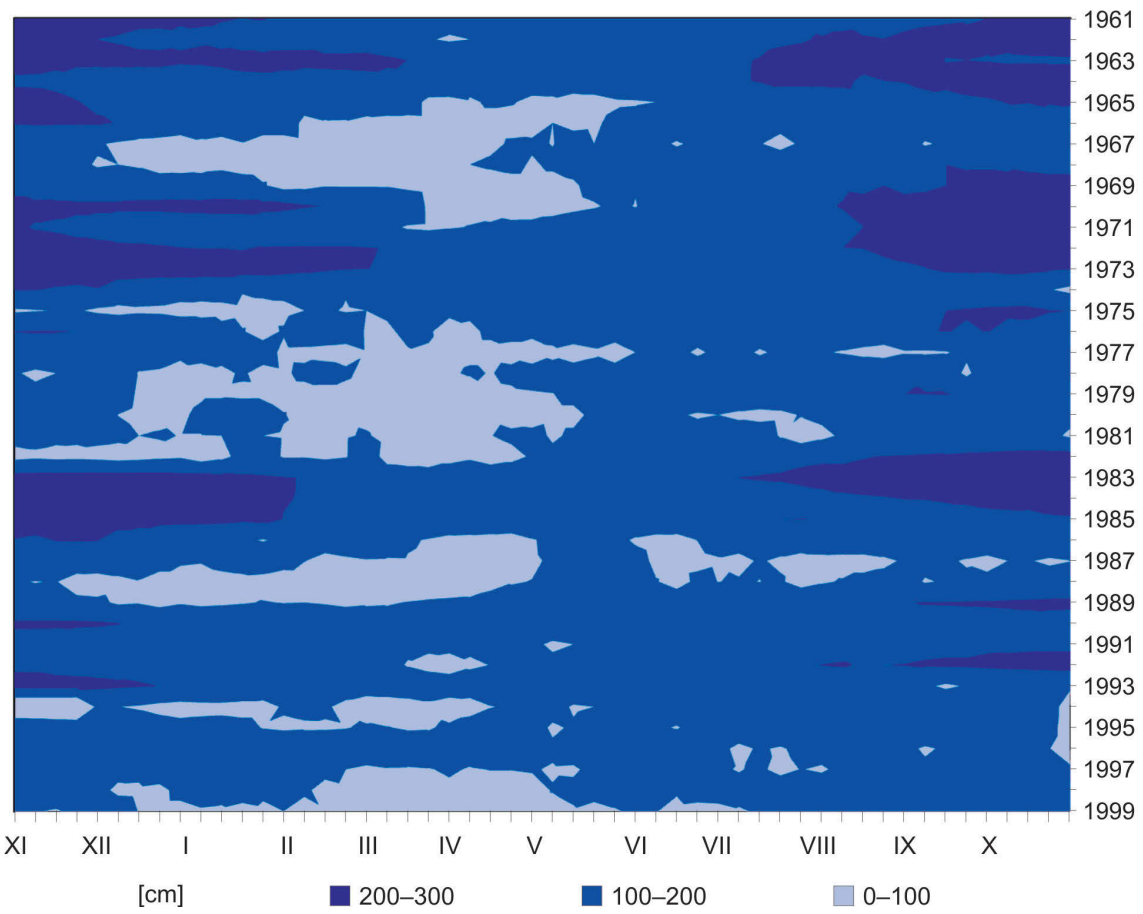

Fig. 4. Weekly groundwater levels (1961-2000) at the IMGW-PIB Buk groundwater station located in the Poznan Plateau (data source: IMGW-PIB)

$75 \%$ of the energy available in the environment is used up for evaporation (Jankowiak, Kędziora 2007). The WetSpass model results confirmed the seasonality of the recharge regime of shallow groundwater, whose level exhibited a downward tendency until the end of the year (Fig. 4).

Many years of observations by the IMGW-PIB (Farat 2004) showed that in the Great Poland area, non-precipitation periods can persist for over a month, and drought occurrences are characterised by the highest incidence levels in Poland. This classifies the region among areas with the highest categories in terms of low retention (Kowalczak et al. 2007). In the summer-autumn low-flow period the influence of precipitation on water table variations is insignificant, and underground recharge of watercourses originates mainly from water reserves retained during the winter period (Chełmicki 1991, Przybyłek, Nowak 2011). This assumption was verified by comparing the WetSpass model results, hydrological methods of underground runoff evaluation and the Processing MODFLOW for Windows PMWIN groundwater filtration model in which water circulation conditions are determined by the hydrodynamic state of the system as well as their zones of recharge and drainage (Graf 2012).
An interesting result was obtained by comparing annual infiltration in each of the land use classes (Table 2). The highest mean annual effective infiltration values were identified in the arable land and grassland classes, which are at the same time characterised by a high range of variation of the values obtained. Forest complexes are characterised by a precipitation infiltration index within $5-18 \%$, whereas for land used for agriculture it is $17-22 \%$. An element which modifies the infiltration capacity of soils in a significant manner is vegetation, which reduces it to about 14$15 \%$, whereas a factor markedly reducing infiltration is land development, which is noticeable in the Poznan city area and its peripheries. These assumptions are confirmed by selected descriptive statistics of effective infiltration, obtained by means of estimation (the WetSpass model) for the applied boundary conditions and hydrologically active surface patterns characterised by, among others, soil type and land use type (Table 3 ).

The simulated effective infiltration values for arable land, grassland and deciduous, coniferous and mixed forests are: 91,78 and $81,68,80 \mathrm{~mm}$, respectively. It was found that forest complexes, due to their high potential of transpiration and interception processes, which are activated particularly in the summer season, lower the re- 
Table 2. Variability range of the effective infiltration volume $[\mathrm{mm}]$ in land use classes - WetSpass model results for the year and winter half-year (1961-2000)

\begin{tabular}{|c|c|c|c|c|c|c|c|c|c|c|}
\hline \multirow{2}{*}{ Land use classes } & \multicolumn{5}{|c|}{ Year } & \multicolumn{5}{|c|}{ Winter half-year } \\
\hline & Min.* & Maks. & Range & $\bar{X}$ & {$[\sigma]$} & Min. & Maks. & Range & $\bar{x}$ & {$[\sigma]$} \\
\hline Developed land (2) & 38.0 & 45.1 & 7.1 & 39.1 & 2.2 & 64.6 & 77.9 & 13.3 & 66.7 & 4.0 \\
\hline Industrial area (3) & 14.8 & 120.4 & 105.6 & 59.1 & 15.2 & 56.8 & 108.1 & 51.4 & 77.9 & 8.9 \\
\hline Technical infrastruc & 36.8 & 151.3 & 114.6 & 70.4 & 37.9 & 82.6 & 119.9 & 37.3 & 97.2 & 9.9 \\
\hline Airport (6) & 32.5 & 62.7 & 30.2 & 47.6 & 7.3 & 30.2 & 51.5 & 21.3 & 39.0 & 5.4 \\
\hline Excavations (7) & 90.0 & 207.2 & 117.2 & 151.7 & 46.9 & 90.0 & 132.4 & 42.4 & 120.4 & 16.5 \\
\hline Developed open land (10) & -26.1 & 158.0 & 184.0 & 49.4 & 23.7 & 76.6 & 132.9 & 56.3 & 94.1 & 10.3 \\
\hline Agriculture (21) & -251.9 & 181.5 & 433.4 & 91.3 & 37.9 & -33.5 & 162.9 & 196.4 & 130.7 & 17.2 \\
\hline Meadow (23) & -187.1 & 187.5 & 374.6 & 77.7 & 37.1 & -12.1 & 159.9 & 172.0 & 128.4 & 9.9 \\
\hline Orchard (29) & -52.2 & 101.1 & 153.3 & 44.6 & 19.4 & 101.9 & 159.7 & 57.8 & 139.2 & 13.2 \\
\hline Deciduous fol & -85.3 & 122.9 & 208.2 & 80.6 & 27.3 & -2.8 & 168.2 & 171.0 & 139.4 & 15.9 \\
\hline Coniferous forest (32) & -55.0 & 114.9 & 169.9 & 78.7 & 14.6 & 12.8 & 161.0 & 148.1 & 133.3 & 12.4 \\
\hline Mixed forest (33) & 30.5 & 136.1 & 105.7 & 96.1 & 18.7 & 82.4 & 151.6 & 69.2 & 129.5 & 11.5 \\
\hline Wetland (44) & 0.0 & 92.9 & 92.9 & 67.7 & 16.6 & 0.0 & 92.9 & 92.9 & 67.7 & 16.6 \\
\hline Motorway (20 & 37.4 & 78.2 & 40.8 & 48.1 & 14.2 & 84.3 & 109.2 & 24.9 & 93.2 & 7.1 \\
\hline Grassland (307) & -182.1 & 179.9 & 362.0 & 96.7 & 71.7 & -11.7 & 150.7 & 162.4 & 127.0 & 12.6 \\
\hline
\end{tabular}

Land use classes - code nos. as per the WetSpass model.

* Data refer to single raster cells $x y=0.0625 \mathrm{~km}^{2} . \bar{X}$ - mean effective infiltration value, $\sigma-$ standard deviation

tention component in the annual water balance, which was confirmed by the results of research conducted by Sophocleous, Perkins (2000), Batelaan (2006) as well as Okoński and Miller (2006).
The shallow groundwater infiltration recharge volumes obtained in the WesSpass model were estimated in relation to the geological and lithological conditions of the Poznan Plateau.

Table 3. Selected statistics of effective infiltration values [mm] for selected reference surface patterns in the Poznan Plateau region - WetSpass model results for the year and the winter half-year (1961-2000)

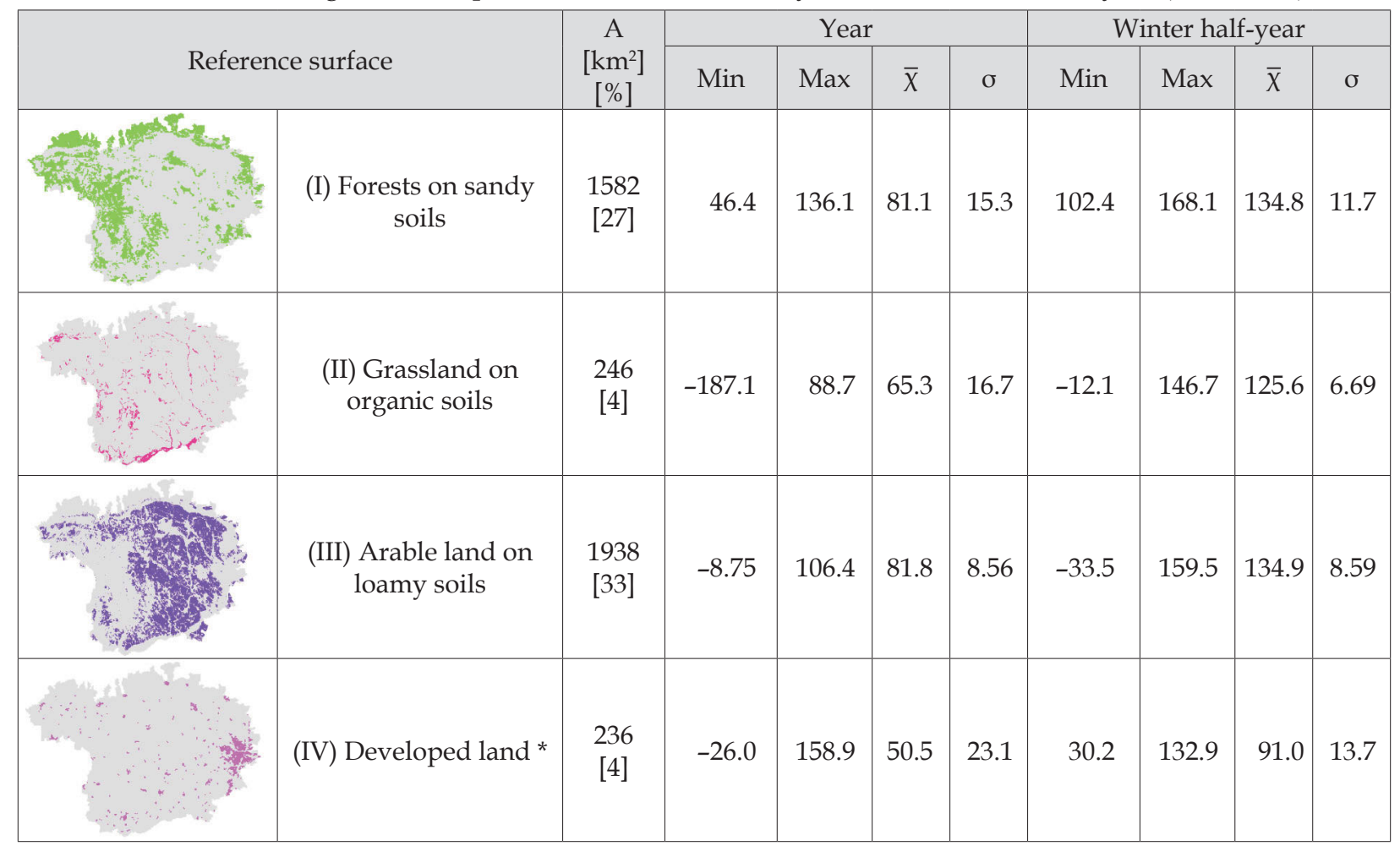

* Developed land (the anthropogenic zone) covers the following land types: built-up and open developed land, industrial, post-exploitation, technical infrastructure; $\bar{X}$ - mean effective infiltration value, $\sigma$ - standard deviation 
A comparison of effective infiltration volumes obtained using the bifactor estimation method (precipitation-subsurface formation lithology) and the multifactor method (the WetSpass model) revealed significant differences. The effective infiltration index, calculated in the WetSpass model as the mean value for the groundwater circulation system, is verified through interrelations occurring between a group of climatic variables, water circulation and physical characteristics of the catchment in relation to the surface runoff and evapotranspiration, being reduced in relation to potential possibilities determined using the geological-infiltration method by about $5-10 \%$ on average.

\section{Conclusions}

An analysis of spatial conditions for infiltration recharge of shallow groundwater in the central part of the Great Poland Lowland (the Poznan Plateau region) was conducted on the basis of simulation studies using a hydrological WetSpass model which included energy and water transfer between the atmosphere, the soil medium and vegetation in relation to shallow groundwater. The application of a water balance model with spatially distributed parameters (a raster model) provided the basis for spatial estimation of precipitation infiltration under average conditions for the year and winter and summer half-years (1961-2000) by taking into account the intensity of effects of continuous and discontinuous hydrological processes.

The results of the WetSpass model confirmed an unfavourable water balance structure in the studied region, with a dominance of evapotranspiration which in many instances exceeded the sums of precipitation in the summer season. Effective recharge of groundwater in the first aquifer, due to precipitation infiltration, takes place in the winter season. This is also proved by the results of analysing the groundwater table. The share of effective infiltration in the water balance structure in the winter season is over $50-60 \%$, whereas in the summer season it is registered as reduced or non-occurring, which is related to high plant transpiration in areas where shallow groundwater is present. An element differentiat- ing the areal distribution of water balance components in an area with a prevalence of flat land (with a slope up to $2^{\circ}$ ) is land use type and soil medium characteristics.

Assuming that the recharge system of the catchment is a complex aggregate characterised by a definite number of diagnostic variables, spatial attributes were selected and assigned to zones representing the state of the active (reference) surface which can potentially generate the appropriate hydrological process. The results and information obtained are stored in the respective model layers and attribute tables, which makes it possible to conduct simulations with varying initial conditions (e.g., changing the land use type) and by applying the GIS as well as by compiling the numerical groundwater model (Graf 2012). The developed system of spatial information about water circulation conditions within the Poznan Plateau, supported by thematic databases on the natural environment with properly encoded information input, can be useful in water resource management, particularly in areas with observed water deficits.

\section{References}

Abu-Saleem A., Al-Zu'bi Y., Rimawi O., Al-Zu'bi J., Alouran N., 2010. Estimation of Water Balance Components in the Hasa Basin with GIS based WetSpass Model. Journal of Agronomy 9: 119-125.

Aish A.M., Batelaan O., De Smedt F., 2010. Distributed recharge estimation for groundwater modeling using Wetspass model, case study - Gaza Strip, Palestine. The Arabian Journal for Science and Engineering 35(1B): 155-163.

Batelaan O., 2006. Phreatology. Characterizing groundwater recharge and discharge using emote sensing, GIS, ecology, hydrochemistry and groundwater modeling. Department of Hydrology and Hydraulic Engineering Faculty of Engineering Vrije Universiteit Brussels.

Batelaan O., De Smedt F., 2001. WetSpass: a flexible, GIS based, distributed recharge methodology for regional groundwater modeling. In: Gehrels H., Peters J., Hoehn E., Jensen K., Leibundgut C., Griffioen J., Webb B., Zaadnoordijk W.J. (eds). Impact of Human Activity on Groundwater Dynamics, IAHS Publ. 269: 11-17.

Blöeschl G., 2001. Scaling in hydrology. Hydrological Processes 15(4): 709-711.

Chełmicki W., 1991. Reżim płytkich wód podziemnych w Polsce (The shallow groundwater regime in Poland). Rozprawy Habilitacyjne UJ 218, Kraków.

Cherkauer D.S., Ansari S.A, 2005. Estimating Ground Water Recharge from Topography, Hydrogeology, and Land Cover. Ground Water 43(1): 102-112.

Choromański J., Michałowski R., 2011. Model hydrologiczny zlewni WetSpa-SGGW zintegrowany z modułem 
obliczeniowym w środowisku ArcGIS (The hydrological catchment model of WetSpa-SGGW integrated with a calculation module in the ArcGIS environment). Przeglad Naukowy - Inżynieria i Kształtowanie Środowiska 53: 196-206.

Dąbrowski S., Kapuściński J., Nowicki K., Przybyłek J., Szczepański A., 2011. Metodyka modelowania matematycznego w badaniach i obliczeniach hydrogeologicznych (Mathematical modelling methodology in hydrogeological research and calculations). Poradnik metodyczny. Bogucki Wyd. Naukowe, Poznań.

Dripps W.R., Bradbury K. R., 2007. A simple daily soil-water balance model for estimating the spatial and temporal distribution of groundwater recharge in temperate humid areas. Hydrogeology Journal 15(3): 433-444.

Dynowska I., Pociask-Karteczka J., 1999. Obieg wody. (Water circulation). In: Starkel L. (ed.), Geografia Polski. Środowisko Przyrodnicze. PWN, Warszawa: 343-392.

Farat R., (ed.), 2004. Atlas klimatu województwa wielkopolskiego (A climatic atlas of the Great Poland Province). IMGW, Oddział w Poznaniu.

Fiedler F.R., Ramirez J.A., 2000. A numerical method for simulating discontinuous shallow flow over an infiltrating surface. International Journal of Numerical Methods in Fluids 32(2): 219-240.

FAOPenman-Monteith (FAO-PM), 1998. Crop evapotranspiration - Guidelines for computing crop water requirements - FAO Irrigation and Drainage Paper, 56. Rome.

Graf R., 2012. Struktura i funkcjonowanie lokalnych systemów krążenia wód podziemnych na obszarze Wysoczyzny Poznanskiej (The structure and functioning of local groundwater circulation systems within the Poznan Plateau). Studia i Prace z Geografii i Geologii 26, Bogucki Wydawnictwo Naukowe, Poznań.

Graf R., Kajewski I., 2013. Kształtowanie się elementów bilansu wodnego w zlewni Mogilnicy na podstawie badań symulacyjnych (The forming of the water balance elements in the Mogilnica catchment basis of simulating investigations). Nauka Przyroda Technologie 7(1): 1-11.

Gutry-Korycka M., 2001. Rola skali w geoekosystemach (The role of scale in geoecosystems). In: Karczewski A., Zwoliński Z., (eds.), Funkcjonowanie geoekosystemów w zróżnicowanych warunkach morfoklimatycznych monitoring, ochrona, edukacja. Stow. Geomorfologów Polskich, Poznań: 157-176.

Hart, D.J., Schoephoester, P.R., and Bradbury, K.R., 2012. Groundwater recharge in Dane County, Wisconsin: Estimating recharge using a GIS-based water-balance model. Wisconsin Geological and Natural History Survey Bulletin 107,11 p.

Jankowiak J., Kędziora A., 2007. Pozytywne i negatywne skutki zmian klimatycznych dla rolnictwa (Positive and negative results of climate change for agriculture) Zmiany klimatu - szanse, zagrożenia i adaptacje, Fundacja UAM, Poznań: 28-46.

Jokiel P., 1994. Zasoby, odnawialność i odpływ wód podziemnych strefy aktywnej wymiany w Polsce. (Resources, recharge and drainage of groundwater in the active exchange zone in Poland). Acta Geographica Lodziensia 66-67.

Kajewski I., 2004. Ocena bilansu wodnego zlewni przy zastosowaniu modelu WetSpass (An assessment of water balance of catchments with the use of the WetSpass model) Modelowanie przepływu wód podziemnych Acta Universitatis Wratislaviensis 2729, Hydrogeologia: 69-80.
Kowalczak P., Mager P., Kępińska-Kasprzak M., 2007. Ocena zasobów wodnych w kontekście przewidywanych zmian klimatu na obszarze województwa wielkopolskiego (An assessment of water resources in the context of projected climate change in the Great Poland Province). Zmiany klimatu szanse, zagrożenia i adaptacje, Fundacja UAM, Poznań: 70-91.

Lin H., Rathbun S., 2003. Hierarchical frameworks for multiscale bridging in hydropedology. In: Pachepsky Y., Radcliffe D.E., Selim H.M., (eds.), Scaling Methods in Soil Physics. CRC Press, Baton Rouge, London, New York, Washington, D.C: 347-371.

Nawalany M., 1999. Zagadnienia skali w hydrogeologii (The problems of scale in hydrology). Biuletyn PIG 388: 179190.

Okoński B., Miler A.T., 2006. Klimatyczny bilans wodny terenów zalesionych Wielkopolski na przykładzie Puszczy Zielonka (The climatic water balance of forested areas of the Great Poland region exampled by the Zielonka Primaeval Forest) Acta Scientarum Polonorum, ser. Formatio Circumiectus 5(20).

Piniewski M., Okruszko T., 2011. Multi-site calibration and validation of the hydrological component of SWAT in a large lowland catchement. Modeling of Hydrological Processes in the Narew Catchement. Geoplanet: Earth and Planetary Sciences: 15-41. DOI 10.1007/978-3-642-190599_2

Pleczyński J., 1981. Odnawialność zasobów wód podziemnych (The recharge potential of groundwater resources). Centr. Urząd Geologii, Wyd. Geol., Warszawa.

Pokojska P., 2004. Aplication and verification of water balance model with distributed parameters (on the example of Rega River Basin). Miscellanea Geographica 11: 139-149.

Ponce M.V., Shetty A.V., 1995. A conceptual model of catchment water balance: formulation and calibration. Journal Hydrology 173: 27-40.

Przybyłek J., Nowak B.; 2011. Wpływ niżówek hydrogeologicznych i odwodnień górniczych na systemy wodonośne Pojezierza Gnieźnieńskiego (The impact of hydrogeological low flows and groundwater drainage by lignite open cast mining on the aquifer systems of the Gniezno Lakeland). Biuletyn PIG 445; seria Hydrogeologia XII/2: 513-527.

Scanlon B.R., Healy R.W., Cook P.G., 2002. Choosing appropriate techniques for quantifying groundwater recharge. Hydrogeology Journal 10(1): 18-39.

Soczyńska U., 1989, System hydrologiczny zlewni i modelowanie procesów obiegu wody (The hydrological catchment system and modelling of water circulation systems) In: Soczyńska U., (ed.). Procesy hydrologiczne. Fizycznogeograficzne podstawy modelowania, PWN, Warszawa: 9-19.

Sophocleous M.A., 2005. Groundwater recharge and sustainability in the High Plains aquifer in Kansas, USA. Hydrogeology Journal 13(2): 351-365.

Sophocleous M.A., Perkins S.P., 2000, Methodology and application of combined watershed and ground-water models in Kansas, Journal of Hydrology 236: 185-201.

Sorooshian S., Hsu K.L., 2008. Hydrological Modelling and the Water Cycle, Springer-Verlag.

Sivapalan M., 2005. Pattern, Proces and Function: Elements of a Unified Theory of Hydrology at the Catchment Scale. Encyclopedia of Hydrological Sciences. P.1. Theory, Organization and Scale. John Wiley \& Sons, London: 193-219. 
Teklebirhan A., Dessie N., Tesfamichael G., 2012. Groundwater Recharge, Evapotranspiration and Surface Runoff Estimation Using WetSpass Modeling Method in Illala Catchment, Northern Ethiopia, Momona Ethiopian Journal of Science (MEJS) 4(2): 96-110.

Toth J., 2009. Gravitational system of groundwater flow. Theory evaluation, utilization. Cambridge University Press.
Urbański J., 2008. GIS w badaniach przyrodniczych (GIS in natural research), Wyd. Uniwer. Gdańskiego, Gdańsk..

Woś A., 2010. Klimat Polski w drugiej połowie XX wieku (The climate of Poland in the second half of the $20^{\text {th }}$ century). Wyd. Naukowe UAM, Poznań.

Yair A., Kossovsky A., 2002. Climate and surface properties: hydrological response of small and semi-arid watersheds. Geomorphology 42(1-2): 43-57. 